\title{
Performance of Federal Buildings in the January 17, 1994 Northridge Earthquake
}

Diana Todd

Ann Bieniawski, editors

Building and Fire Research Laboratory

Gaithersburg, Maryland 20899

\section{NGT}

United States Department of Commerce logy Administration

QC al Institute of Standards and Technology

100

.456

N0.5574

1995 



\section{Performance of Federal Buildings in the January 17, 1994 Northridge Earthquake}

Diana Todd

Ann Bieniawski, editors

January 1995

Building and Fire Research Laboratory

National Institute of Standards and Technology

Gaithersburg, MD 20899

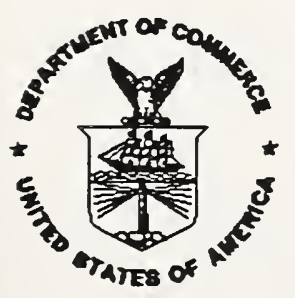

U.S. Department of Commerce

Ronald H. Brown, Secretary

Technology Administration

Mary L. Good, Under Secretary for Technology

National Institute of Standards and Technology

Arati A. Prabhakar, Director 



\begin{abstract}
On January 17, 1994, a magnitude 6.8 earthquake struck Northridge, California, in the northeast suburbs of Los Angeles. This report summarizes information compiled by the Interagency Committee on Seismic Safety in Construction (ICSSC) on the performance of federally-owned buildings in the Northridge earthquake. Eleven agencies reported that they owned buildings in the affected area. Collectively, over 4000 federally-owned buildings were shaken; approximately 120 were damaged by the quake. Only two sites were reported to have suffered major damage; most damage was minor. The estimated cost to repair the damaged buildings is $\$ 127$ million.
\end{abstract}

Keywords: building performance, building technology, earthquake, federal buildings, Northridge earthquake, seismic 


\section{Table of Contents}

Executive Summary $\ldots \ldots \ldots \ldots \ldots \ldots \ldots \ldots \ldots \ldots \ldots$

U.S. Department of Agriculture $\ldots \ldots \ldots \ldots \ldots \ldots \ldots \ldots \ldots$

Federal Bureau of Prisons $\ldots \ldots \ldots \ldots \ldots \ldots \ldots \ldots \ldots$

Department of Commerce $\ldots \ldots \ldots \ldots \ldots \ldots \ldots \ldots \ldots$

Department of Defense . . . . . . . . . . . . . . . . 8

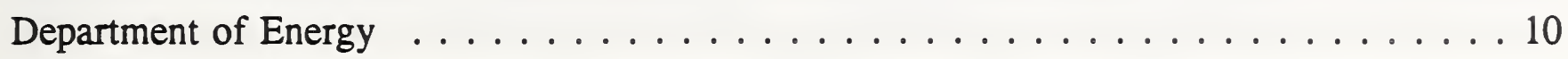

General Services Administration $\ldots \ldots \ldots \ldots \ldots \ldots \ldots \ldots$

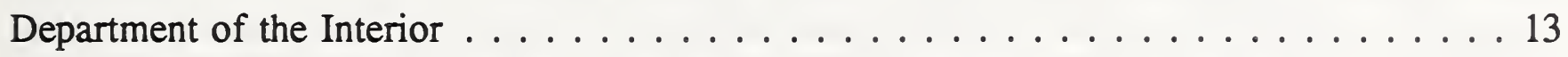

Department of Justice . . . . . . . . . . . . . . . . . . . 14

National Aeronautics and Space Administration . . . . . . . . . . . . 15

U.S. Postal Service . . . . . . . . . . . . . . . . . . . . . 17

Department of Veterans Affairs . . . . . . . . . . . . . . . . . . . . 19

Appendix A . . . . . . . . . . . . . . . . . . 21 


\section{Executive Summary}

Following the January 17, 1994 magnitude 6.8 Northridge, California earthquake, interest was expressed within the Federal government concerning the performance of Federal buildings during the earthquake. The Interagency Committee on Seismic Safety in Construction (ICSSC) determined that a brief report on this subject would be useful. The ICSSC therefore solicited from member agencies the reports that make up this document in order to collect in one document the pertinent information. A copy of the letter soliciting the collaboration of buildingowning agencies is included in Appendix A. The body of this paper presents the reports received from member agencies that owned buildings in the affected area.

Of the 23 departments or agencies that responded to the request for information, 12 reported that they had no owned buildings in the affected area (Table 1). The other 11 agencies collectively own over 4000 buildings in the affected area, about 120 of which were damaged by the earthquake. The estimated cost of repairing the damaged structures totals about $\$ 127$ million. Table 2 summarizes the information on the damaged buildings and the estimated costs of repair.

There were no major injuries or fatalities reported in the damaged buildings. The earthquake occurred at 4:31 a.m on a Federal holiday, Martin Luther King's Birthday, therefore most Federally-owned buildings, other than hospitals and residences, were not occupied. However, even if the earthquake had occurred while the buildings were fully occupied, the number of deaths and major injuries would have been relatively small because, with a few exceptions, the damage that did occur was minor.

Only two sites were reported to have buildings that suffered serious structural damage. One of the sites was a 60 -year-old U.S. Forest Service office/barracks building at Los Padres National Forest, which was in marginal condition before the quake and was badly damaged and subsequently condemned. The other site with major damage was the Veterans Affairs medical complex in Sepulveda, about eight $\mathrm{km}$ from the epicenter. Of the 44 buildings in the complex, 17 were undamaged, 23 suffered minor damage, and 4 experienced serious damage.

Information on whether buildings had been seismically upgraded prior to the earthquake was not readily available in many agencies. The few agencies that did own seismically rehabilitated buildings reported that they had performed well during the January 17 shaking.

In general, the information submitted by agencies owning buildings in the area affected by the Northridge earthquake suggests that Federal buildings performed similarly to non-Federal buildings. No unusual building behavior was reported.

The following departments and agencies did not respond to the request for information: Environmental Protection Agency, Department of Labor, Small Business Administration. 
Table 1: Federal Agencies with No Owned Buildings in the Area Affected by the Northridge Earthquake

Department of Education

Federal Emergency Management Agency

Department of Health and Human Services

Department of Housing and Urban Development

U.S. Information Agency

National Science Foundation

Nuclear Regulatory Commission

Smithsonian Institution

Department of State

Tennessee Valley Authority

Department of Transportation

Department of the Treasury 
Table 2: Seismic Performance of Federally-Owned Buildings

Affected by the Northridge Earthquake

\begin{tabular}{|c|c|c|c|c|c|}
\hline Agency & $\begin{array}{l}\text { Number } \\
\text { of } \\
\text { Damaged } \\
\text { Buildings } \\
\end{array}$ & $\begin{array}{c}\text { Total } \\
\text { Number } \\
\text { of } \\
\text { Buildings } \\
\end{array}$ & $\begin{array}{c}\text { Epicentral } \\
\text { Distance } \\
\text { km } \\
\end{array}$ & $\begin{array}{c}\text { Type } \\
\text { of } \\
\text { Damage } \\
\end{array}$ & $\begin{array}{l}\text { Approximate } \\
\text { Cost } \\
\text { to } \\
\text { Repair } \\
\end{array}$ \\
\hline $\begin{array}{l}\text { Dept. of Agriculture } \\
\text { ARS } \\
\text { NFS } \\
\end{array}$ & $\begin{array}{l}1 \\
6 \\
\end{array}$ & $\begin{array}{r}5 \\
400 \\
\end{array}$ & $\begin{array}{c}40 \mathrm{~km} \\
30-45 \mathrm{~km}\end{array}$ & $\begin{array}{c}\text { very minor } \\
\text { minor to major }\end{array}$ & $\begin{array}{c}-0- \\
\$ 309,000\end{array}$ \\
\hline $\begin{array}{l}\text { Bureau of Prisons } \\
\text { FCI } \\
\text { MDC }\end{array}$ & $\begin{array}{l}0 \\
1 \\
\end{array}$ & $\begin{array}{r}\mathrm{NA}_{1} \\
1 \\
\end{array}$ & $\begin{array}{l}60 \mathrm{~km} \\
40 \mathrm{~km} \\
\end{array}$ & $\begin{array}{c}\text { none } \\
\text { minor nonstructural } \\
\end{array}$ & $\begin{array}{l}-0- \\
\text { NA }\end{array}$ \\
\hline Dept. of Commerce & 0 & 2 & NA & none & -0 \\
\hline $\begin{array}{l}\text { Dept. of Defense } \\
\text { Army } \\
\text { Navy } \\
\text { Air Force } \\
\end{array}$ & $\begin{array}{l}3 \\
5 \\
0 \\
\end{array}$ & $\begin{array}{r}41 \\
2661 \\
367 \\
\end{array}$ & $\begin{array}{r}<17 \mathrm{~km} \\
<66 \mathrm{~km} \\
48 \mathrm{~km} \\
\end{array}$ & $\begin{array}{c}\text { minor nonstructural } \\
\text { minor } \\
\text { none }\end{array}$ & $\begin{array}{c}\$ 100,000 \\
\$ 645,000 \\
-0-\end{array}$ \\
\hline Dept. of Energy & 6 & 81 & $10 \mathrm{~km}$ & minor & $\$ 197,000$ \\
\hline $\begin{array}{l}\text { General Services } \\
\text { Administration }\end{array}$ & 22 & 22 & $<80 \mathrm{~km}$ & minor & $\$ 5,200,000$ \\
\hline $\begin{array}{l}\text { Dept. of the Interior } \\
\text { NPS } \\
\text { Fish \& Wildlife }\end{array}$ & $\begin{array}{l}0 \\
0 \\
\end{array}$ & $\begin{array}{r}2 \\
13 \\
\end{array}$ & $\begin{array}{c}30 \& 77 \mathrm{~km} \\
48-72 \mathrm{~km} \\
\end{array}$ & $\begin{array}{l}\text { none } \\
\text { none }\end{array}$ & $\begin{array}{l}-0- \\
-0- \\
\end{array}$ \\
\hline Dept. of Justice & 0 & 8 & $48-125 \mathrm{~km}$ & none & -0 \\
\hline $\begin{array}{l}\text { NASA } \\
\text { JPL } \\
\text { Downey } \\
\end{array}$ & $\begin{array}{l}4 \\
8 \\
\end{array}$ & $\begin{array}{r}144 \\
43 \\
\end{array}$ & $\begin{array}{l}50 \mathrm{~km} \\
80 \mathrm{~km} \\
\end{array}$ & $\begin{array}{l}\text { minor } \\
\text { minor }\end{array}$ & $\begin{array}{l}\$ 210,000 \\
\$ 268,000 \\
\end{array}$ \\
\hline U.S. Postal Service & $\begin{array}{l}12 \\
12 \\
14\end{array}$ & $110_{2}$ & $<40 \mathrm{~km}$ & $\begin{array}{c}\text { non-structural } \\
\text { structural/non-structural } \\
\text { significant structural }\end{array}$ & $\$ 10,500,000_{2}$ \\
\hline $\begin{array}{l}\text { Dept. of Veterans Affairs } \\
\text { Sepulveda \& LA } \\
\text { Long Beach } \\
\text { Loma Linda }\end{array}$ & $\begin{array}{c}>29 \\
0 \\
0\end{array}$ & $\begin{array}{r}275 \\
24 \\
\text { NA }\end{array}$ & $\begin{array}{l}8-35 \mathrm{~km} \\
64 \mathrm{~km} \\
96 \mathrm{~km}\end{array}$ & $\begin{array}{l}\text { minor to major } \\
\text { none } \\
\text { none }\end{array}$ & $\begin{array}{c}\$ 110,000,000 \\
-0- \\
-0\end{array}$ \\
\hline
\end{tabular}

, NA - information not available

2 This number includes both owned and leased buildings 


\section{U.S. Department of Agriculture}

Department of Agriculture (USDA) agencies which own facilities have been canvassed to determine the impact of the Northridge Earthquake on USDA-owned buildings. USDA's two largest agencies, Agricultural Research Service (ARS) and Forest Service (FS), own buildings in the area. Below is a summary of the information received from these two agencies. Other USDA building-owning agencies, including the Animal and Plant Health Inspection Service, the Farmers Home Administration and the Soil Conservation Service, report no owned buildings in Los Angeles, Orange, and Ventura Counties.

How many buildings (or other structures) does your Agency own in the affected area? Give a general description of their sizes, types, uses and approximate distance from the epicenter.

Answer: ARS owns five structures/buildings located at 263 South Chester Avenue, Pasadena, CA (Los Angeles County). This location is a Fruit and Vegetable Chemistry Laboratory with Support and Administrative Offices. The structures are as follows:

$\begin{array}{llll}\text { Description/Usage } & \text { Year } & \text { Gross } & \text { Type of } \\ \text { Built } & \underline{\text { Sq } \mathrm{Ft}^{1}} & \text { Construction }\end{array}$

Main Building 1/Research and Administration

1949 16,500 Reinforced Concrete Masonry Unit

Isolated Operations/

Headhouse and Research

$1968 \quad 830 \quad$ Reinforced Concrete Masonry Unit

Boiler House and Garage/

Storage and Boiler Operations $1949625 \quad$ Wood Frame

Solvent Storage/Storage

and Electrical Equipment

$1949150 \quad$ Reinforced Concrete Masonry Unit

Greenhouse/Plant Research $\quad 1982 \quad 2,200$ Glass and Metal Frame

The Pasadena location is approximately 25 miles from the epicenter.

The Forest Service reports over 400 buildings in the area, including buildings in the Angeles National Forest and the Los Padres National Forest. Types of buildings range from storage

\footnotetext{
${ }^{1}$ Agency reports are reproduced in this document as they were received. Numbers shown in the actual reports have not been converted to SI units. The following conversions can be used:$$
1 \mathrm{ft}=0.3048 \mathrm{~m} \quad 1 \mathrm{sq} \mathrm{ft}=0.0929 \mathrm{sq} \mathrm{m} \quad 1 \mathrm{mi}=1.61 \mathrm{~km}
$$ 
sheds to barracks and small office buildings. Northridge is about 19 miles from the Saugus District Headquarters and 28 1/2 miles from the Forest Supervisor's Office at Angeles National Forest.

How many of these suffered no damage, minor damage, major damage, complete collapse? How many had to be evacuated and for how long? Were there any major injuries or fatalities?

Answer: The main ARS building suffered very minor damage. The location personnel report only broken glassware and fallen objects. The facility was immediately cleaned up and the glass replaced. Because the earthquake happened during a federal holiday, the facilities were unoccupied, therefore, no injuries or fatalities occurred.

The Forest Service reports damage to six buildings at two locations. At the Angeles National Forest in Arcadia, California four buildings sustained light damage. The Administration building (block construction) at Pyramid Lake recreation site has large cracks to patch and paint at an estimated $\$ 4,000$. A modular office building at Saugus District Headquarters has distended tie down straps which must be tightened at an estimated $\$ 4,000$. The modular Forest Supervisor's Office sustained floor damage of $\$ 1,000$ and two warehouse buildings at the Forest Supervisor's Office sustained minimal wall damage. At the Los Padres National Forest, a 60 year old office/barracks buildings at Temescal Station was in marginal condition prior to the earthquake, was damaged extensively, and has been condemned as a total loss. The cost for replacement is about $\$ 300,000$. There were no injuries or fatalities reported.

What is the estimated dollar value of direct losses to your Agency's property? To the building itself? To the building contents?

Answer: The ARS property and facilities were inspected, and no visible damage reported. There was minimal damage to the building contents.

The FS estimate of repair or replacement is about $\$ 309,000$ for the six damaged buildings. Building contents were not damaged significantly.

Had any of your buildings been seismically rehabilitated prior to the quake? How did those buildings perform (no damage, minor damage, major damage, collapse)?

Answer: When the earthquake occurred, the ARS main building was undergoing seismic upgrades to the floors, walls and roof to make it in compliance with current codes. This work was completed in June 1994 and was not affected by the earthquake.

The Forest Service reports no prior seismic rehabilitation at the damaged buildings. Building assessments were done in January 1994.

Cite any instances of Federal building performance that was unexpected, or not consistent with the performance of neighboring buildings of like kind. (Cite both unusually good and unusually poor performance). 
Answer: The ARS facilities apparently performed as expected given the types of construction and distances from the epicenter. There were no eyewitnesses in the facilities during the earthquake.

The Forest Service reports that the Temescal Station Building was in marginal condition prior to the Northridge Earthquake and was damaged extensively. 


\section{Federal Bureau of Prisons}

The Bureau of Prisons (BOP) operates two institutions in the Los Angeles area. The institutions are the Federal Correctional Institution (FCI), Terminal Island and the Metropolitan Detention Center (MDC), Los Angeles, California.

FCI, Terminal Island is located on the southwest tip of Terminal Island in the Los Angeles Harbor, between San Pedro and Long Beach. The buildings are single and two story, with the majority of the construction dating from 1938 . There was no damage reported at FCI, Terminal Island.

MDC, Los Angeles is located in downtown Los Angeles, at the corner of Alameda and Aliso Streets. The institution is a single high-rise building opened in 1989. The building was under construction when an earthquake occurred in the Los Angeles area in 1987. There was no structural damage to the building resulting from the Northridge Earthquake. Nonstructural damage was limited to a cracked tube in one of the institution's boilers caused by the boiler shifting from its mounting; loss of the central processing unit on the building management system; and cracking in joints between sections of gypsum board. Operations were not severely impaired due to any of the damage.

\section{Department of Commerce}

The DOC's National Oceanic and Atmospheric Administration owns two buildings in Los Angeles County. One building is 1,314 square feet and houses equipment used by the National Weather Service. The other building is 195 square feet and is a well house. Neither building houses personnel and no damage to the structures due to the Northridge earthquake has been observed. The exact distance from the epicenter is not known. Based on the purpose and size, these buildings likely had not undergone any type of seismic rehabilitation prior to the earthquake. 


\section{Department of Defense}

Following is a description of the performance of buildings and other structures owned by this department in the area affected by the Northridge earthquake. Buildings affected include those of the Army, Navy, and Air Force:

\section{The U.S. Army}

1. There are forty-one buildings located at Army installations in the vicinity of the Northridge earthquake. The buildings range in size from 10,000 - 20,000 square feet. The buildings are structural steel frame with masonry walls. They are used for barracks, training classes, dining facilities, administration, and general purpose areas. The buildings are located within $16.9 \mathrm{~km}$ of the epicenter.

2. There were no major injuries or fatalities. Three buildings suffered minor non-structural damage. No buildings had to be evacuated.

3. Damage to the buildings was minimal. However, the following are noteworthy:

(a) USARC Van Nuys maintenance shop -- Damage limited to cracked masonry walls. The cost of repair is estimated to be $\$ 25,000$.

(b) USARC Van Nuys administration building -- Damage limited to cracked masonry walls. The cost of repair is estimated to be $\$ 60,000$.

(c) USARC Van Nuys maintenance building -- Damage limited to cracked masonry walls. The cost of repair is estimated to be $\$ 15,000$.

4. Prior to the earthquake none of the buildings had been seismically rehabilitated.

5. Federal building performance was consistent with other buildings located in the area.

\section{The U.S. Navy}

1. There are 2,661 buildings located at Navy installations in the vicinity of the Northridge earthquake. There are very few unreinforced masonry buildings located on the sites. Buildings are used for barracks, administration, training, warehouses, shops, magazines, and hangers. Building size varies according to use. They are located within $66 \mathrm{~km}$ of the epicenter.

2. There were no major injuries or fatalities.

3. Damage to the buildings was minimal. However, the following are noteworthy:

(a) Marine Reserve Training Center - One building was damaged. Damage was confined to cracking of concrete floors and roof diaphragms. In addition, the concrete walls have 
widely dispersed hairline cracks, but this did not constitute serious damage. On the basis of plans adopted prior to the earthquake, the Navy will no longer occupy the building. New tenants of this structure will be required to make repairs before occupancy.

(b) A Marine $\mathrm{R}$ erve building - Extensive nonstructural damage and no structural damage. Estimated $r c$ ir costs not mentioned.

(c) Long Beach Naval Station - One building experienced extensive nonstructural damage to a suspended ceiling. Estimated cost of repair is $\$ 60,000$.

(d) Long Beach Naval Shipyard - One building, five stories in height, experienced minor nonstructural damage in the form of plaster cracks, dropped ceiling tiles, and elevator rails that had to be realigned. Estimated repair cost not mentioned.

(e) NAWS Point Mugu - A hangar experienced some damage to a shear wall at the roof line. The hangar also experienced some localized damage to cross bracing that was attributed to previously loosened connection bolts. Estimated cost of repair is $\$ 30,000$.

(f) Lon Beach Naval Shipyard - Four piers has some damage to expansion joints with damaged and broken crane rails. Estimated cost of repair is $\$ 555,000$.

4. Files do not mention if buildings have been seismically rehabilitated prior to the earthquake.

5. Federal building performance was consistent with performance of neighboring buildings.

\section{The U.S. Air Force}

1. There are 367 buildings at Air Force facilities located within the area affected by the Northridge earthquake. The structures/buildings range in size from $60-150,000$ square feet. The buildings are constructed with concrete foundations. They are used for housing, administration, training, research, and other general purpose areas. The main base is located approximately $48 \mathrm{~km}$ from the epicenter of the quake.

2. There were no major injuries or fatalities.

3. There was no damage to the 367 buildings.

4. Information has not been provided confirming if buildings were seismically rehabilitated prior to the quake.

5. Performance of Federal buildings was consistent with performance of other buildings in the area. 


\section{Department of Energy}

The Department of Energy's Energy Technology Engineering Center (ETEC) is located in the area affected by the Northridge earthquake.

The ETEC complex consists of 81 buildings ranging from offices to warehouses to large test facilities. ETEC is located on a 90 acre site in the Santa Suzana mountains, about $10 \mathrm{~km}$ West of the earthquake epicenter. Damage, resulting from the $0.3 \mathrm{~g}$ ground motion (measured by onsite USGS SMA's), consisted of fallen ceiling panels, light fixtures, wall cracks and a few bent beams and was, generally, relatively minor to about 6 buildings. Three facilities suffered damage to cranes that required the replacement of structural bolts and recertification. The foundation and support structure for a gaseous nitrogen storage system were damaged. One storage vessel was removed from service pending repair of its foundation. Because all buildings at ETEC were designed and constructed to stringent UBC earthquake standards, damage sustained by the structures, other than that described above, was light. Most facilities were located on bedrock. One facility SMA recorded $0.6 \mathrm{~g}(\mathrm{~N}-\mathrm{S})$ and $0.4 \mathrm{~g}(\mathrm{E}-\mathrm{W})$ on the sixth floor. To date, $\$ 97 \mathrm{~K}$ has been expended and an additional $\$ 100 \mathrm{~K}$ is expected to be required to complete repairs. Also, because of the time that the earthquake event took place $(4: 31 \mathrm{a} . \mathrm{m}$.) no personnel were on-site. As a result, no injuries or fatalities were reported. 


\section{General Services Administration}

Q. How many buildings does your agency own in the affected area? Give a general description of their sizes, types, use and approximate distance from the epicenter.

A. GSA owns 22 buildings in the affected area. The 22 buildings comprise the following structural types:
o Wood Frame
o Steel Moment Resisting Frame
o Steel Braced Frame
o Light Metal Frame
o Steel Frame w/Concrete Shear Walls
o Reinforced Concrete Moment Resisting Frame
o Precast Concrete Frame
o Reinforced Masonry
o Unreinforced Masonry (URM)
o Tilt-up Concrete

Building sizes range from 5,000 square feet to 764,553 square feet. Most of the buildings are offices; however, there are several parking structures. All buildings are located within approximately 50 miles from the epicenter.

Q. How many of these suffered no damage, minor damage, major damage, or complete collapse? How many had to be evacuated, and for how long? Were there any major injuries or fatalities?
A. No damage:
None
Minor damage:
22 buildings
Major damage:
None
Complete Collapse: None

Three agencies had to be evacuated from leased buildings due to major building damage. These agencies were relocated to other buildings and will not return. According to records there were no major injuries or fatalities.

Q. What is the estimated dollar value of direct losses to your agency's property? To the building itself? To the building contents?

A. Estimated dollar value of direct losses to GSA property is approximately $\$ 5,200,000$; building damage is approximately $\$ 4,200,000$ and building contents and nonstructural damage is approximately $\$ 1,000,000$. 
Q. Had any agency buildings been seismically rehabilitated prior to the earthquake? How did those buildings perform (no damage, minor damage, major damage, or collapse)?

A. According to our records only the Pasadena Courthouse had been rehabilitated prior to the earthquake. Overall, the building performed well, however, there were many cracks and the building will be evaluated by an independent structural engineer.

Q. Cite any instances of Federal building performance that was unexpected, or not consistent with the performance of neighboring buildings of like kind. (Cite both unusually good and unusually poor performance).

A. We were very surprised at how well GSA-owned buildings performed and have no unusual behavior to report. 


\section{Department of the Interior}

\section{Bureau of Mines}

No facilities in area affected by earthquake (Orange, Los Angeles and Ventura Counties).

\section{Office of Surface Mining}

No facilities in area affected by earthquake.

\section{Bureau of Land Management}

No facilities in area affected by earthquake.

\section{U.S. Geological Survey}

No facilities in area affected by earthquake.

\section{Bureau of Reclamation}

No facilities in area affected by earthquake.

\section{Bureau of Indian Affairs}

No facilities in Orange, Los Angeles or Ventura Counties. Closest facility is Sherman Indian High School in Riverside County; no damage.

\section{Minerals Management Service}

No onshore facilities in area affected by earthquake. Oil platforms 31 miles offshore Los Angeles and Ventura Counties were not subjected to extreme ground motions and were not damaged.

\section{National Park Service}

Two buildings in area affected by earthquake: 1. The Santa Monica Mountains National Recreation Area Visitors Center and Headquarters located in a privately-owned commercial building in Los Angeles County 19 miles from the epicenter, and 2. The Channel Islands National Monument Visitor Center, a Federally-owned building located in Oxnard, Ventura County, 48 miles from the epicenter. Neither building sustained damage.

\section{National Biological Survey}

Same Channel Islands facility as National Park Service.

\section{U.S. Fish and Wildlife Service}

Thirteen buildings were in the area affected by the earthquake. Eleven were in the Hopper Mountain National Wildlife Refuge located in Ventura, Ventura County, 45 miles from the epicenter, and two buildings with leased space, an office building and a warehouse, located in Torrance, Los Angeles County, 30 miles from the epicenter. None of these buildings sustained any damage. 


\section{Department of Justice}

Excluding the Federal Bureau of Prisons, which is reported separately, the Department has:

- an installation consisting of two border patrol stations, approximately 2,900 square feet (SF) in Camarillo in Ventura County, about 30 miles from the epicenter;

- a 10,000 SF hangar and 1,751 SF of office space at the Long Beach Municipal Airport in Los Angeles County, about 37 miles from the epicenter; and

- an installation consisting of four signaling relay stations, approximately 6,800 SF, in San Clemente in Orange County, about 78 miles from the epicenter.

These facilities suffered no damage; therefore there is no estimated dollar value of direct losses to property, buildings, or building's contents. The Department does not maintain detailed information concerning the seismic rehabilitation status of its buildings or records of performance that was unexpected or not consistent with the performance of neighboring buildings of like kind. 


\section{National Aeronautics and Space Administration}

NASA has two facilities located in the affected area, the Jet Propulsion Laboratory in Pasadena and the NASA Industrial Plant in Downey.

NASA Jet Propulsion Laboratory, Pasadena, CA

1. How many buildings does your agency own in the affected area? The Jet Propulsion Laboratory in Pasadena consists of 144 buildings.

a. Description of types, sizes, and uses: The types of construction include concrete, steel, masonry and wood frame. The total gross floor area is 2,181,655 square feet for all 144 buildings. There are 20 large buildings (greater than 30,000 square feet) that have a combined gross area of 1,500,000 square feet. There are 124 smaller buildings (less than 30,000 square feet) with a combined area of 681,655 square feet. The buildings are used for offices, research laboratories and related activities in support of space science research, spacecraft development activities and spacecraft tracking and data acquisition.

b. Distance from epicenter: Approximately 31 miles east of the epicenter.

2. How many of these suffered no damage, minor damage, major damage, complete collapse? Four buildings suffered minor damage.

a. How many had to be evacuated and for how long? None were evacuated.

b. Were there any major injuries or fatalities? No.

3. What is the estimated dollar value of direct losses to your agency's property? The estimated cost of repairing the affected buildings and other minor damages like broken ceiling tiles, and miscellaneous utility pipe leakage is $\$ 210,000$.

a. To the building itself? N/A.

b. To the building contents? No damage to building contents was reported.

4. Had any of your buildings been seismically rehabilitated prior to that quake? Yes. How did those buildings perform (no damage, minor damage, major damage, collapse)? No structural damage to any rehabilitated building. Minor damage due to water pipe breaks.

5. Cite any instances of Federal building performance that was unexpected, or not consistent with the performance of neighboring buildings of like kind. Cite both unusually good and unusually poor performance). Considering the number of buildings at the site and the damage incurred as a result of the Northridge Earthquake, it was felt that the buildings performed very well. 


\section{NASA Industrial Plant, Downey, CA}

1. How many buildings (or other structures) does your agency own in the affected area? The NASA Industrial Plant in Downey, CA consists of 43 buildings.

a. Description of types, sizes, and uses: The types of construction include concrete, steel, metal siding, masonry and wood frame. The total gross area of all 43 buildings is approximately $1,730,500$ square feet. There are six large buildings (greater than 30,000 square feet) that have a combined area of $1,480,500$ square feet. There are 37 smaller buildings (less than 30,000 square feet) with a combined area of 250,000 square feet. The buildings are used for offices, manufacturing, laboratories and related support activities for shuttle orbiter manufacturing and production.

b. Distance from epicenter: Approximately 50 miles.

2. How many of these suffered no damage, minor damage, major damage, complete collapse? Eight buildings suffered minor damage.

a. How many had to be evacuated and for how long? None were evacuated.

b. Were there any major injuries or fatalities? No.

3. What is the estimated dollar value of direct losses to your agency's property? The estimated cost to repair the eight damaged buildings at Downey was $\$ 268,000$.

a. To the building itself? Repair items include suspended ceilings, drywall/plaster, fire sprinkler, plumbing, electrical, HVAC, bridge cranes, and elevators.

b. To the building contents? Space Shuttle tooling, the test stand and thermal protection system tiles experienced damage.

4. Had any of your buildings been seismically rehabilitated prior to the quake? Yes. How did those buildings perform (no damage, minor damage, major damage, collapse)? No structural damage occurred in any rehabilitated building.

5. Cite any instances of Federal building performance that was unexpected, or not consistent with the performance of neighboring buildings of like kind. Cite both unusually good and unusually poor performance). Considering the number of buildings at the site and the damage incurred as a result of the Northridge Earthquake, it was felt that the buildings' performance was good. 


\section{U.S. Postal Service}

1. How many buildings (or other structures) does your Agency own in the affected area? Give a general description of the sizes, types, uses and approximate distance from the epicenter.

Immediately following the earthquake 110 buildings were given a rapid evaluation. Of these 33 are owned and 77 are leased. These ranged from small Post Office branches to large mail processing and distribution facilities. Many Post Offices also house carrier operations. The buildings are scattered within 25 miles of the epicenter.

With few exceptions, the Post Office stations and branches (Customer Service Facilities) fell into four building types:

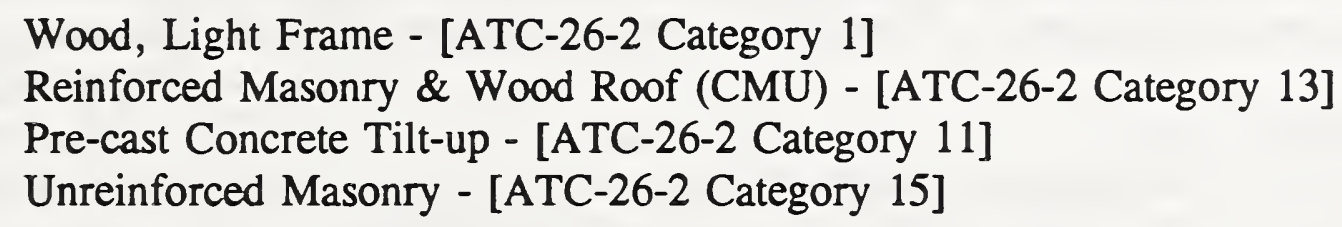

Wood, Light Frame - [ATC-26-2 Category 1]

Reinforced Masonry \& Wood Roof (CMU) - [ATC-26-2 Category 13]

Pre-cast Concrete Tilt-up - [ATC-26-2 Category 11]

Unreinforced Masonry - [ATC-26-2 Category 15]

The Santa Clarita Processing \& Distribution Center (P\&DC) was in the final phase of construction at the time of the earthquake. The Postal Service had accepted the administration section of the building. The mail processing portion of the facility had not been accepted since construction of the mechanized equipment for processing mail had not been completed. The building suffered no apparent structural damage, but did incur floor, ceiling, lighting, mechanical, and mechanization damage.

Other large facilities included: Los Angeles Bulk Mail Center (BMC), Los Angeles P\&DC, Bakersfield P\&DC, Marina (Inglewood) P\&DC, Oxnard P\&DC, Pasadena P\&DC, Van Nuys P\&DC, Worldway Airport Mail Center. No structural damage occurred in these facilities - they experienced non-structural damage to ceilings, lighting, lookout galleries and cosmetic damage.

Two Processing and Distribution Centers and seventeen Customer Service facilities were initially closed for suspected structural damage or lack of electrical power. Of those that remained closed for more than a day, operations were temporarily established in tents and mobile units. As of March 25, 1994 only the leased Chatsworth Main Post Office and the Santa Clarita P\&DC remained closed. Chatsworth operations were temporarily relocated to new space. The new Santa Clarita plant was only partially occupied by administration staff before the earthquake and they have been relocated to nearby facilities - mail processing operations had not been activated as of March 25, 1994.

The Santa Clarita General Mail Facility consisted of a single story work/storage area (1020 ft x $527 \mathrm{ft}$ ) divided by seismic joints into six contiguous structures; a two story office/training/cafeteria/locker room wing with second story offices (148 ft x $677 \mathrm{ft}$ ) divided by seismic joints into three contiguous structures; and a two story administration wing ( $95 \mathrm{ft} x 100$ ft) separated by a seismic joint. The structure consists of steel moment frames with glue laminated purlins, a panelized timber roof and tilt-up concrete walls. There are four wood framed mechanical mezzanines for air handling units. 
* The site had been regraded with fill up to $70 \mathrm{ft}$. Settlements of between 6 inches and 8 inches were experienced. Damage included: numerous cracks in the slab on grade; local damage to precast concrete wall panels, crib walls, and retaining walls; and numerous roof leaks indicating possible damage to roof diaphragm. Wide spread damage to AHU vibration isolators and metal duct work. Numerous breaks in fire and water piping.

* Peak ground acceleration estimated at $0.6 \mathrm{~g}$ horizontal and between $0.25 \mathrm{~g}$ to $0.6 \mathrm{~g}$ vertically. Differential settlement at site attributed to settlement and some ground displacement. Second floor stud wall failures caused by concrete failure around pin floor anchors where $\mathrm{UBC}$ forces were exceeded $0.3 \mathrm{~g}$ vs $1.0 \mathrm{~g}$ to $1.5 \mathrm{~g}$ estimated accelerations. Building was designed for life safety performance.

2. How many of these suffered no damage, minor damage, complete collapse? How many had to be evacuated and for how long? Were there any major injuries or fatalities?

No damage observed $\ldots \ldots \ldots \ldots \ldots \ldots \ldots \ldots \ldots$

No structural and/or moderate non-structural damage . . . . . . . . 12

Moderate structural damage and/or significant non-structural damage . . 12

Significant damage and/or is a known vulnerable building system . . . 14

Only two facilities had to be evacuated for a long period of time. There were no major injuries or fatalities.

3. What is the estimated dollar value of direct losses to your Agency's property? To the building itself? To the building contents?

The estimated cost of damage sustained to leased and owned Customer Service Facilities is $\$ 5$ million. Leased buildings are generally the responsibility of the owner.

The estimated cost of damage to the Santa Clarita P\&DC is $\$ 4.5$ million for the building and $\$ 1.0$ million to reinforce the foundation (due to ground settlement). The construction contractor is responsible for repairs to the mechanization (mail processing) systems, which had not been accepted by the Postal Service at the time of the earthquake.

4. Had any of your buildings been seismically rehabilitated prior to the earthquake? How did those buildings perform (no damage, minor damage, major damage, collapse)?

As far as known, none of the owned buildings had been seismically rehabilitated.

5. Cite any instances of Federal Building performance that was unexpected, or not consistent with the performance of neighboring buildings of the like kind. (Cite both unusually good and unusually poor performance.)

The Santa Clarita P\&DC facility, did not perform as expected. URS conducted an analysis of the damage and concluded that the forces experienced by the building exceeded the UBC design forces - their conclusion was that the building was designed in conformance with the UBC seismic criteria. 


\section{Department of Veterans Affairs}

The Department of Veterans Affairs owns approximately 300 buildings at five different locations in the vicinity of the Northridge earthquake site. There was no loss of life or collapse of any buildings from the earthquake. The total cost of structural damage to the buildings and building contents was estimated at about $\$ 60$ million and $\$ 50$ million respectively. The following is a brief summary of each medical facility in the affected area:

\section{VAMC Sepulveda}

Sepulveda is located five miles from the epicenter. The maximum horizontal and vertical ground accelerations recorded by USGS instruments at the site were $0.94 \mathrm{~g}$ and $0.48 \mathrm{~g}$, respectively. The most seriously affected structure was the Main Hospital Building \#3, which suffered extensive structural and nonstructural damage which resulted in the permanent evacuation of 350 patients. Building \#3 is a 6-story concrete and masonry shear wall structure constructed in the mid-fifties. The building consists of six wings, each separated by four inch seismic joints. Exterior walls are of either reinforced concrete or reinforced brick construction. The vertical and horizontal movement of the building during the earthquake caused extensive damage at every level of the wings and on either side of the seismic joints. The majority of other buildings at the site are one to three stories, and are of reinforced concrete construction. The amount of reinforcing used was typical of the period when these buildings were constructed in 1955. The construction does not meet the current code requirements for reinforced concrete construction in regions of high seismicity, but the construction met or exceeded the seismic code requirements at the time of design. Of the 44 buildings at the site, four buildings suffered significant structural damage affecting re-occupancy, 23 buildings suffered some minor structural damage, and 17 buildings suffered no structural damage. Overall the buildings performed very well.

\section{VAMC West Los Angeles}

This site is located about 12 miles from the epicenter. The maximum horizontal and vertical ground acceleration recorded by USGS instruments at the site were $0.18 \mathrm{~g}$ and $0.14 \mathrm{~g}$ respectively. A large number of buildings of various ages and sizes are located at this site. The 820-bed main hospital, Building \#500, suffered structural and nonstructural damage to the penthouse located on the roof of the 6-story structure. This steel frame building was constructed in 1974 with interstitial floors. The lateral forces below the penthouse are transferred though diagonal steel bracing between columns. The penthouse above the roof is 83 feet square, 30 feet tall, with light metal stud walls on all four sides. Lateral forces in the penthouse were intended to be resisted by the exterior wall stucco and flat diagonal steel straps in the wall construction. Since there was no steel diagonal bracing or any moment connections to transfer the lateral loads, the penthouse framing performed poorly. Repairs are currently underway. There was no structural damage to the main building frame.

\section{Outpatient Clinic, Downtown Los Angeles}

This six-story steel moment-resisting frame building is located about 22 miles from the epicenter. Recently occupied, it was designed for the latest VA seismic code. The building's 
structural framing behaved very well. However, there was minor non-structural damage around the stair towers. Water pipes had ruptured at a few places. Overall the building escaped any serious damage.

\section{VAMC Long Beach}

This facility is located about 40 miles from the epicenter. None of the buildings suffered any structural or nonstructural damage. There are 24 buildings, mostly of concrete shear walls one or two stories high. The main hospital building is a 12-story concrete shear wall building constructed in 1967. The building does not conform to the latest seismic code requirements, but complied to the seismic codes that existed at the time of construction. Currently, the building is being seismically strengthened using base isolators at approximately 144 columns.

\section{VAMC Loma Linda}

Located about 60 miles from the epicenter, the main hospital building was constructed shortly after the February 9, 1971, San Fernando Earthquake. No structural or non-structural damage was reported at this site. 
Appendix A 
June 20, 1994

(name \& address of ICSSC member)

Dear (name of ICSSC member):

Considerable Congressional interest has been expressed over the last months concerning the performance of Federal buildings during the Northridge Earthquake. It seems that a brief ICSSC report on this subject would be a useful document for ICSSC members and their managements to use in responding to future inquiries of this nature. I believe such a document could be developed with a minimum amount of effort on your part.

Please prepare a two or three page summary of the performance of buildings and other structures owned by your agency in the area affected by the Northridge earthquake (Los Angeles, Orange, and Ventura Counties). If your agency had no buildings in the affected area, I would appreciate knowing that as well. The ICSSC Technical Secretariat will compile the responses and prepare introductory and summary material. The document will be distributed to the ICSSC Full Committee and the steering Committee prior to any release.

I suggest you address the following items in your brief report:

- How many buildings (or other structures) does your agency own in the affected area? Give a general description of their sizes, types and uses. (Specific building addresses are not necessary, but do give approximate distance from the epicenter.)

- How many of these suffered no damage, minor damage, major damage, complete collapse? How many had to be evacuated and for how long? Were there any major injuries or fatalities?

- What is the estimated dollar value of direct losses to your agency's property? To the building itself? To the building contents?

- Had any of your buildings been seismically rehabilitated prior to the quake? How did those buildings perform (no damage, minor damage, major damage, collapse)?

- Cite any instances of Federal building performance that was unexpected, or not consistent with the performance of neighboring buildings of like kind. (Cite both unusually good and unusually poor performance).

Please let me have your input by July 20, 1994. Thank you for your assistance in developing this useful ICSSC document.

sincerely,

Richard N. Wright, Chairman

Interagency Committee on Seismic Safety in Construction 

